\title{
Long-term results of surgical treatment of non-small cell lung cancer in patients over 75 years of age
}

\author{
Krystian Pawlak ${ }^{1}$, Piotr Gabryel ${ }^{1}$, Anna Kujawska², Mariusz Kasprzyk ${ }^{1}$, Cezary Piwkowski ${ }^{1}$, Błażej Kuffel ${ }^{2}$, \\ Wojciech Dyszkiewicz ${ }^{1}$
}

${ }^{1}$ Department of Thoracic Surgery, Poznan University of Medical Sciences, Poznan, Poland

${ }^{2}$ Students' Scientific Association at the Department of Thoracic Surgery, Poznan University of Medical Sciences, Poznan, Poland

Kardiochirugia i Torakochirurgia Polska 2018; 15 (2): 65-71

\begin{abstract}
Introduction: Patients over 75 years of age, who, in addition, often have already exceeded the average life expectancy, in the Polish population on average 77.4 years, are the subject of discussion concerning the most appropriate choice of treatment. Aim: To analyse the long-term results in elderly patients over 75 years of age with lung cancer who underwent curative pulmonary resection.

Material and methods: 166 patients aged from 75 to 85 (mean: $77.4 \pm 2.3$ ) operated on for non-small cell lung cancer (NSCLC) were included in this study. There were $128(77 \%)$ men and 38 (23\%) women.

Results: Lobectomy, including bilobectomy, was performed in 122 (74\%) patients, pneumonectomy in 8 (5\%) patients, and wedge resections or segmentectomy in the remaining $36 \mathrm{pa}$ tients. Squamous or adenocarcinoma was diagnosed in $46 \%$ and $42 \%$ of cases respectively. Clinical stage I A was diagnosed in $36(22 \%)$ patients, I B in 51 (31\%), IIA in 30 (18\%), IIB in 19 $(11 \%)$ and IIIA in $30(18 \%)$ of our cases. The early 30 -day postoperative mortality was $5 \%$ whilst postoperative morbidity occurred in $47 \%$ of cases. The five-year survival rate was $30 \%$. In statistical analysis, the TNM classification ( $p=0.0490)$, the number of postoperative complications $(p=0.0001)$ and obstructive atelectasis requiring repeat bronchofibroscopic aspirations $(p=0.0137)$ in the early postoperative period most negatively influenced the long-term survival in the whole study group.

Conclusions: Surgical resections for lung cancer in patients over 75 years of age are characterised by a relatively good long-term prognosis. Careful and strictly detailed preoperative selection, particularly of patients with pulmonary comorbidities and the earliest possible diagnosis of a lung tumour, can reduce the occurrence of these postoperative complications in elderly patients, which negatively influence long-term results.
\end{abstract}

Key words: lung cancer, elderly patients, long-term survival.

\section{Streszczenie}

Wstęp: Najwłaściwszy sposób leczenia raka płuca i możliwości radykalnego leczenia operacyjnego u najstarszych pacjentów, powyżej 75. roku życia, często w wieku przekraczającym średni czas przeżycia w populacji Polski (77,4 roku), stanowią podmiot dyskusji.

Cel: Ocena odległych wyników radykalnego leczenia operacyjnego u chorych powyżej 75. roku życia z niedrobnokomórkowym rakiem płuca (NDRP).

Materiat i metody: Do badania włączono 166 chorych w wieku od 75 do 85 lat (średnia 77,4 $\pm 2,3$ roku), operowanych z powodu NDRP. Wśród nich było 128 (77\%) mężczyzn i 38 (23\%) kobiet.

Wyniki: U 122 (74\%) chorych wykonano lobektomię lub bilobektomię, u 8 (5\%) pneumonektomię, natomiast u pozostałych 36 (21\%) chorych - resekcję klinową lub segmentektomię. Najczęściej u badanych rozpoznawano raka płaskonabłonkowego (47\%) oraz gruczolakoraka (42\%). Stopień kliniczny I A stwierdzono u 36 (22\%) chorych, I B u 51 (31\%), II A u 30 (18\%), II B u 19 (11\%), a III A u pozostałych $30(18 \%)$ chorych. Wczesna, 30-dniowa śmiertelność pooperacyjna wyniosła 5\%. Powikłania we wczesnym okresie pooperacyjnym wystąpity u $47 \%$ badanych. Pięcioletnie przeżycie po operacji uzyskano u $30 \%$ badanych. W analizie statystycznej wykazano, że stopień zaawansowania nowotworu ( $p=0,049)$, liczba powikłań pooperacyjnych $(p=0,0001)$ oraz pooperacyjna niedodma wymagająca powtarzalnych bronchofiberoskopii $(p=0,0137)$ miały najistotniejszy negatywny wpływ na przeżycie odległe wśród chorych.

Wnioski: Resekcje płucne u chorych powyżej 75. roku życia pozwalają uzyskać satysfakcjonujące wyniki pod względem odległego przeżycia pod warunkiem ostrożnej i wnikliwej przedoperacyjnej selekcji pacjentów, zwłaszcza tych, którzy są obciążeni chorobami wspótistniejącymi, oraz wczesnego rozpoznania choroby. Może to zmniejszyć częstość występowania tych powikłań pooperacyjnych, które negatywnie wpływają na przeżycia odległe.

Słowa kluczowe: rak płuca, chorzy w wieku podeszłym, przeżycia odległe.

Address for correspondence: Krystian Pawlak MD, Department of Thoracic Surgery, Poznan University of Medical Sciences, 62 Szamarzewskiego St, 60-569 Poznan, Poland, phone: +48 509835 550, e-mail: krystianp@hotmail.com Received: 16.01.2018, accepted: 12.02.2018. 


\section{Introduction}

Surgical treatment of lung cancer in elderly patients still poses a challenge for thoracic surgeons. The peak of morbidity for that disease concerns patients over 65 years of age [1]. The multiple progressive somatic changes in the cardiovascular and respiratory system during aging and the high frequency of comorbidities in the elderly are additional perioperative risk factors, especially when more extensive lung resections are needed [1]. Radical pulmonary resections in that age group of patients are associated with both a higher rate of serious and life-threatening early postoperative complications as well as an uncertain long-term postoperative outcome. In numerous reports, it is emphasised that age alone is not a contraindication for surgical treatment of elderly patients; careful selection of those patients as well as an interdisciplinary assessment prior to surgery should be performed [2-5]. Patients over 75 years of age, who, in addition, often have already exceeded the average life expectancy, in the Polish population on average 77.4 years, are the subject of discussion concerning the most appropriate choice of treatment.

\section{Aim}

The aim of this study is to analyse the long-term results in elderly patients over 75 years of age with lung cancer who underwent curative pulmonary resection.

\section{Material and methods}

Between January 2007 and September 2015, 175 elderly patients over 75 years of age underwent pulmonary resections due to non-small cell lung cancer. Nine (5.1\%) of these patients who died in the early 30 postoperative days were excluded from the statistical analysis of the factors affecting long-term survival.

Ultimately, 166 patients aged from 75 to 85 (mean: 77.4 \pm 2.3 ) were included in this study. Among them, there were 128 (77\%) men and 38 (23\%) women.

Prior to surgery, blood tests, chest computed tomography (CT), bronchofibroscopy with the use of autofluorescence, respiratory function tests $\left(\mathrm{FEV}_{1}, \mathrm{FEV}_{1} / \mathrm{VC}, \mathrm{VC}\right)$ with the Lungtest 1000 spirometer (Mes Ltd. Krakow, Poland) as

Table I. Characteristics of patients $(N=166)$

\begin{tabular}{lc} 
Parameter & Result, $\bar{x} \pm$ SD (min.-max.) \\
Age [years] & $77.46 \pm 2.34(75-85)$ \\
\hline ppvFEV $_{1}(\%)$ & $65.3 \pm 16.5(31.7-105.1)$ \\
\hline ppvFVC (\%) & $73.6 \pm 16.6(32.6-136.42)$ \\
\hline Hospital stay (POD) & $10.8 \pm 9.3(1-64)$ \\
\hline Chest tube removal (POD) & $4.3 \pm 2.8(1-25)$ \\
\hline Parameter & Percentage (number) \\
\hline Gender (male) & $77(128)$ \\
\hline
\end{tabular}

$\overline{\bar{x}-\text { mean value. SD - standard deviation, min.-max. -minimal-maximal value. }}$ well as abdominal ultrasound examination and echocardiography were routinely performed in all patients. In addition, since 2009, a positron emission tomography (PET) $\mathrm{CT}$ scan has also been routinely performed on every patient eligible for surgical treatment. If preoperative CT or PET CT scans revealed N2 value, endobronchial ultrasound (EBUS) or mediastinoscopy was performed before surgery to verify the clinical stage of the tumour. Data on coexisting diseases and completed oncological treatment of other malignant tumours in the past were obtained during subjective examinations. Among the total number of comorbidities presented in Table I, arterial hypertension (63\%) and chronic obstructive pulmonary disease (25\%) were the most frequently observed among our patients. In the preoperative objective examination, the general state of the patient's performance according to the WHO scale and the perioperative risk according to the physical status classification system of the American Society of Anesthesiologists (ASA) were evaluated in all patients. Preoperative characteristics of the studied patients are shown in Table I.

A histopathological diagnosis prior to surgery was obtained in $143(86 \%)$ of our patients, mainly by the use of bronchofibroscopic brushing, fine-needle biopsy, EBUS or mediastinoscopy, whilst in the remaining 23 (17\%) patients, lung cancer was diagnosed based on an intraoperative frozen section.

In all our patients, the surgical procedures were performed under general anaesthesia using the Roberts Shaw double lumen endotracheal tube. In 119 (71\%) patients who were operated on by anterio-lateral thoracotomy, epidural anaesthesia with continuous infusion of $0.125-0.25 \%$ bupivacaine at the level of Th5-Th6 was additionally used. In the remaining 47 (28\%) patients with lung cancer in clinical stage I or II, pulmonary resections were performed using minimally invasive video-assisted thoracic surgery (VATS). Routine postoperative pleural drainage was passive in patients after pneumonectomy or active $\left(-20 \mathrm{~cm} \mathrm{H}_{2} \mathrm{O}\right.$ suction drainage) in those patients who underwent less extensive resections. The drains were maintained from 1 to 25 days postoperatively (mean: $4.4 \pm 2.8$ ). Antibiotic and antithrombotic prophylaxis was used in all patients during the postoperative hospital stay.

The postoperative histopathological stage of cancer was evaluated based on the $7^{\text {th }}$ edition of the TNM Classification of Lung Cancer according to the Union for International Cancer Control (IICC) and the American Joint Committee on Cancer (AJCC) from 2009. The hospital stay ranged from 5 to 64 days with a mean of $10.8 \pm 9.3$.

The long-term survival of the patients was assessed based on reports from an oncological or a thoracic surgery clinic. In the case of an absence of current data in the case of outpatients, a direct telephone contact with patients was used. Data concerning further postoperative treatment were obtained in all studied patients. Adjuvant chemotherapy or adjuvant radiotherapy were used postoperatively in $21(13 \%)$ and in 19 (11\%) patients, respectively. The follow- 
up started on postoperative day (POD) 31 (day zero) and ranged from 1 to 107 months (mean: $50.8 \pm 26.8$ ).

\section{Statistical analysis}

Statistical analysis was performed using Statistica v 10.0 MRI Series 0411-P (StatSoft, Inc. USA) and Graph Pad Prism 6 (Graph Pad Software, Inc. USA). The analysis of postoperative survival was performed using the Kaplan-Meier test. The influence of the risk factors on patients' survival was assessed using the log-rank test. The results were considered statistically significant at a $p$ level $<0.05$.

\section{Results}

Among all 166 patients included in this analysis, complete pulmonary resections were performed in 130 (78\%) patients. Lobectomy, including bilobectomy, was performed the most commonly and concerned 122 (74\%) patients, whilst in 8 (5\%) patients, pneumonectomy was necessary for radical treatment. In the remaining 36 patients with incomplete resections, wedge resection or segmentectomy were performed in 31 (19\%) patients and in 5 (3\%) patients, respectively.

Out of the total number of early postoperative complications, supraventricular arrhythmias (42-25\%) and obstructive atelectasis that required repetitive bronchofibroscopic aspirations (15-9\%) were most frequently observed (Table II).

Nine (5\%) patients required repeat surgery in the early postoperative period. In 5 cases (1 after pneumonectomy and 4 after lobectomy), redo operations were performed followed by bleeding into the pleural cavity, while in the other 4 patients, it was due to prolonged air leakage after lobectomy $(n=1)$ and segmentectomy $(n=1)$, bronchopleural fistula after bilobectomy $(n=1)$ and VATS lobectomy $(n=1)$.

Among the histological types of lung cancer, the most common was squamous cell cancer, which was observed in 77 (46\%), and adenocarcinoma concerning 69 (42\%) of cases. Other types of lung cancer (large cell cancer, pleomorphic cancer, lepidic cancer, adenoid cystic cancer) were diagnosed in the remaining 20 (12\%) patients. Based on the $7^{\text {th }}$ edition of the TNM Classification, clinical stage I A was diagnosed in 36 (22\%) patients, I B in 51 (31\%), IIA 30 (18\%), IIB in $19(11 \%)$ and IIIA in 30 (18\%) of our cases. Clinical stages IIIB or IV was not observed among the studied patients. Lymphadenectomy was performed in all patients. Pulmonary resection was radical in $89 \%$ of patients, whilst in $11 \%$ of cases, it was non-radical due to the $\mathrm{N}_{2}$ value (Table III).

The early 30-day postoperative complications shown in Table IV occurred in a total of 78 (47\%) patients. Among these, one complication was observed in 36 patients, whereas at least 2 complications occurred in the remaining 39 patients.

Out of the total of 166 patients included in the study, $123(74 \%)$ survived at least 1 year. Out of the 108 patients who were observed for more than 3 postoperative years, $81(75 \%)$ survived at least 1 year, whilst 51 (47\%) of them survived at least 3 years. Among the 54 patients with a complete 5-year follow-up, 38 (70\%) survived at least 1 year, 26 (48\%) at least 3 years, and 16 (30\%) at least 5 years. The overall postoperative survival of all studied patients is shown in Figure 1.

Table II. Influence of postoperative complications on long-term survival

\begin{tabular}{|c|c|c|c|c|}
\hline Characteristics & & $\begin{array}{c}\text { Total number } \\
\text { of patients } \\
(N=166) \\
\%(n)\end{array}$ & $\begin{array}{c}\text { 1/3/5-year } \\
\text { survival } \\
(\%)\end{array}$ & $P$-value ${ }^{1}$ \\
\hline \multirow{2}{*}{$\begin{array}{l}\text { Total } \\
\text { complications }\end{array}$} & Yes & $47(78)$ & $63 / 33 / 25$ & \multirow[t]{2}{*}{0.1608} \\
\hline & No & & $83 / 61 / 37$ & \\
\hline \multirow{3}{*}{$\begin{array}{l}\text { Number of } \\
\text { complications }\end{array}$} & 0 & $55(92)$ & $83 / 59 / 33$ & \multirow[t]{3}{*}{0.0001} \\
\hline & 1 & $21(35)$ & $77 / 48 / 43$ & \\
\hline & $>1$ & $24(39)$ & $52 / 21 / 16$ & \\
\hline \multirow[t]{2}{*}{ Repeat surgery } & Yes & $5(9)$ & $67 / 32 / 0$ & \multirow[t]{2}{*}{0.3580} \\
\hline & No & & $84 / 45 / 32$ & \\
\hline \multirow{2}{*}{$\begin{array}{l}\text { Blood } \\
\text { transfusion }>1 U\end{array}$} & Yes & $11(18)$ & $61 / 17 / 17$ & \multirow[t]{2}{*}{0.0792} \\
\hline & No & & $76 / 52 / 34$ & \\
\hline \multirow[t]{2}{*}{ Atrial fibrillation } & Yes & $25(42)$ & $55 / 27 / 23$ & \multirow[t]{2}{*}{0.3524} \\
\hline & No & & $81 / 56 / 34$ & \\
\hline \multirow{2}{*}{$\begin{array}{l}\text { Atelectasis } \\
\text { requiring } \\
\text { aspiration }\end{array}$} & Yes & $9(15)$ & $38 / 13 / 0$ & \multirow[t]{2}{*}{0.0137} \\
\hline & No & & $79 / 51 / 35$ & \\
\hline \multirow{2}{*}{$\begin{array}{l}\text { Broncho-pleural } \\
\text { fistula }\end{array}$} & Yes & $1(1)$ & - & \multirow[t]{2}{*}{-} \\
\hline & No & & & \\
\hline \multirow{2}{*}{$\begin{array}{l}\text { Residual } \\
\text { pneumothorax }\end{array}$} & Yes & $5(8)$ & $76 / 41 / 0$ & \multirow[t]{2}{*}{0.9401} \\
\hline & No & & $74 / 48 / 32$ & \\
\hline \multirow{2}{*}{$\begin{array}{l}\text { Additional chest } \\
\text { tube }\end{array}$} & Yes & $4(6)$ & $40 / 0 / 0$ & \multirow[t]{2}{*}{0.0857} \\
\hline & No & & $77 / 48 / 27$ & \\
\hline \multirow[t]{2}{*}{ Wound infection } & Yes & $1(1)$ & - & \multirow[t]{2}{*}{-} \\
\hline & No & & & \\
\hline \multirow{2}{*}{$\begin{array}{l}\text { Prolonged air } \\
\text { leakage }>7 \text { days }\end{array}$} & Yes & $5(8)$ & $76 / 31 / 31$ & \multirow[t]{2}{*}{0.0962} \\
\hline & No & & $75 / 48 / 32$ & \\
\hline \multirow{2}{*}{$\begin{array}{l}\text { Mechanical } \\
\text { ventilation } \\
>48 \mathrm{~h}\end{array}$} & Yes & $4(6)$ & $33 / 0 / 0$ & \multirow[t]{2}{*}{0,0974} \\
\hline & No & & $76 / 49 / 27$ & \\
\hline \multirow{2}{*}{$\begin{array}{l}\text { Pulmonary } \\
\text { thrombosis }\end{array}$} & Yes & $1(1)$ & - & \multirow[t]{2}{*}{-} \\
\hline & No & & & \\
\hline \multirow{2}{*}{$\begin{array}{l}\text { Postoperative } \\
\text { psychosis }\end{array}$} & Yes & $5(8)$ & $100 / 72 / 72$ & \multirow[t]{2}{*}{0.0824} \\
\hline & No & & $73 / 48 / 30$ & \\
\hline \multirow[t]{2}{*}{ Cerebral stroke } & Yes & $1(1)$ & - & \multirow[t]{2}{*}{-} \\
\hline & No & & & \\
\hline
\end{tabular}

$P$-value $<0.05$ - statistically significant, $p \geq 0.05$ - statistically not significant. ${ }^{1}$ Log-rank test. 
Table III. Influence of histological type of lung cancer on long-term survival

\begin{tabular}{|c|c|c|c|}
\hline Characteristics & $\begin{array}{c}\text { Total number } \\
\text { of patients } \\
(N=166) \\
\%(n)\end{array}$ & $\begin{array}{c}\text { 1/3/5-year } \\
\text { survival } \\
(\%)\end{array}$ & $P$-value ${ }^{1}$ \\
\hline \multicolumn{3}{|l|}{ Histological type: } & 0.3558 \\
\hline Squamous cell cancer & $46(77)$ & $78 / 52 / 39$ & \\
\hline Adenocarcinoma & $42(69)$ & $77 / 46 / 28$ & \\
\hline Others & $12(20)$ & $55 / 42 / 28$ & \\
\hline \multicolumn{3}{|l|}{ Stage of cancer (TNM): } & 0.0490 \\
\hline $\mathrm{I} A$ & $22(36)$ & $83 / 63 / 41$ & \\
\hline I B & $31(51)$ & $80 / 55 / 36$ & \\
\hline$\| \mathrm{A}$ & $18(30)$ & $77 / 46 / 34$ & \\
\hline II B & $11(19)$ & $63 / 33 / 8$ & \\
\hline III A & $17(28)$ & $57 / 28 / 28$ & \\
\hline \multicolumn{3}{|l|}{$N$ value: } & 0.3965 \\
\hline NO & $67(111)$ & $77 / 53 / 31$ & \\
\hline N1 & $22(36)$ & $75 / 42 / 29$ & \\
\hline N2 & 11 (19) & $58 / 27 / 27$ & \\
\hline
\end{tabular}

$P$-value $<0.05$ - statistically significant, $p \geq 0.05-$ not statistically significant. ${ }^{1}$ Log-rank test.

The statistical analysis revealed that the stage of cancer according the TNM classification ( $p=0.0490)$ (Fig. 2), the number of postoperative complications ( $p=0.0001)$ (Fig. 3) and the obstructive atelectasis that required repetitive bronchofibroscopic aspirations ( $p=0.0137$ ) (Fig. 4) in the early postoperative period had the most significant influence on the long-term survival in the whole study group. The other preoperative and postoperative factors listed in Tables II-V had no significant influence on the patients' long-term survival.

\section{Discussion}

The number of elderly patients with lung cancer has been constantly rising. This is mainly related to the prolonged life expectancy in the whole population, as well as the possibility of earlier and more appropriate diagnostics and technological development of modern medicine. Patients over the age of 75 years already constitute a significant proportion of the lung cancer population, reaching approximately 30-50\% $[2,6]$. Although surgical treatment of elderly patients poses a significant challenge for thoracic surgeons, as it is associated with a higher risk of postoperative morbidity and mortality compared to younger patients, it is still the best choice for the treatment of lung cancer in elderly patients [3, 6]. Despite the postoperative disturbances, the long-term results after the surgical treatment of lung cancer in this age group are still better compared to the alternative radiotherapy or chemotherapy [7]. Only patients after stereotactic body ra-
Table IV. Influence of preoperative factors on long-term survival

\begin{tabular}{|c|c|c|c|c|}
\hline Characteristics & & $\begin{array}{c}\text { Total number } \\
\text { of patients } \\
(N=166) \\
\%(n)\end{array}$ & $\begin{array}{c}\text { 1/3/5-year } \\
\text { survival } \\
(\%)\end{array}$ & $P$-value ${ }^{1}$ \\
\hline \multirow[t]{2}{*}{ Age [years] } & $<80$ & 78 (129) & $76 / 51 / 32$ & 0.1092 \\
\hline & $\geq 80$ & & $64 / 30 / 24$ & \\
\hline \multirow[t]{2}{*}{ Gender } & Male & 77 (128) & $74 / 49 / 35$ & 0.6998 \\
\hline & Female & & $79 / 44 / 16$ & \\
\hline \multirow[t]{2}{*}{$\operatorname{ppvFEV}_{1}(\%)$} & $<50 \%$ & $22(37)$ & $75 / 48 / 32$ & 0.8137 \\
\hline & $\geq 50 \%$ & & 73/47/39 & \\
\hline \multirow[t]{2}{*}{ ppvFVC (\%) } & $<50 \%$ & $5 \%(9)$ & $44 / 15 / 0$ & 0.6666 \\
\hline & $\geq 50 \%$ & & $78 / 50 / 34$ & \\
\hline \multirow[t]{2}{*}{ Comorbidities } & Yes & $81(134)$ & $74 / 47 / 30$ & 0.7482 \\
\hline & No & & $75 / 49 / 32$ & \\
\hline \multirow[t]{2}{*}{ Diabetes } & Yes & $16(26)$ & $81 / 65 / 32$ & 0.3052 \\
\hline & No & & $73 / 45 / 30$ & \\
\hline \multirow{2}{*}{$\begin{array}{l}\text { Myocardial } \\
\text { infarction } \\
\text { in the past }\end{array}$} & Yes & $1(2)$ & - & - \\
\hline & No & & - & \\
\hline \multirow{2}{*}{$\begin{array}{l}\text { Circulatory } \\
\text { failure }\end{array}$} & Yes & $1(2)$ & - & - \\
\hline & No & & - & \\
\hline \multirow[t]{2}{*}{ COPD } & Yes & $36(59)$ & $75 / 49 / 33$ & 0.6224 \\
\hline & No & & $73 / 47 / 28$ & \\
\hline \multirow{2}{*}{$\begin{array}{l}\text { Arterial } \\
\text { hypertension }\end{array}$} & Yes & $69(114)$ & $75 / 48 / 29$ & 0.9466 \\
\hline & No & & $71 / 47 / 33$ & \\
\hline \multirow{2}{*}{$\begin{array}{l}\text { Ischemic } \\
\text { heart disease }\end{array}$} & Yes & $5(8)$ & $88 / 50 / 25$ & 0.9175 \\
\hline & No & & $73 / 48 / 32$ & \\
\hline \multirow{2}{*}{$\begin{array}{l}\text { Other } \\
\text { malignant } \\
\text { disease }\end{array}$} & Yes & $12(20)$ & $65 / 28 / 21$ & 0.0899 \\
\hline & No & & $87 / 38 / 29$ & \\
\hline
\end{tabular}

$P$-value $<0.05$ - statistically significant, $p \geq 0.05$ - not statistically significant. ${ }^{1}$ Log-rank test.

diotherapy, due to early stage lung cancer of less than $2 \mathrm{~cm}$, might benefit from a similar survival as those after radical pulmonary resections [8].

Lung cancer in elderly patients usually grows slower, has a lower rate of metastasis than those tumours in younger patients, and is diagnosed at a relatively early stage; however, the average life expectancy of the palliated treated patients is evaluated to be as short as 1.65 years after diagnosis [6].

As it has frequently been reported, the most important factors for satisfactory results of operative treatment in elderly patients with lung cancer are proper clinical preoperative selection of the patients as well as early diagnosis of the tumour to avoid the most extensive resections that cause decreased long-term survival, which ranges from 


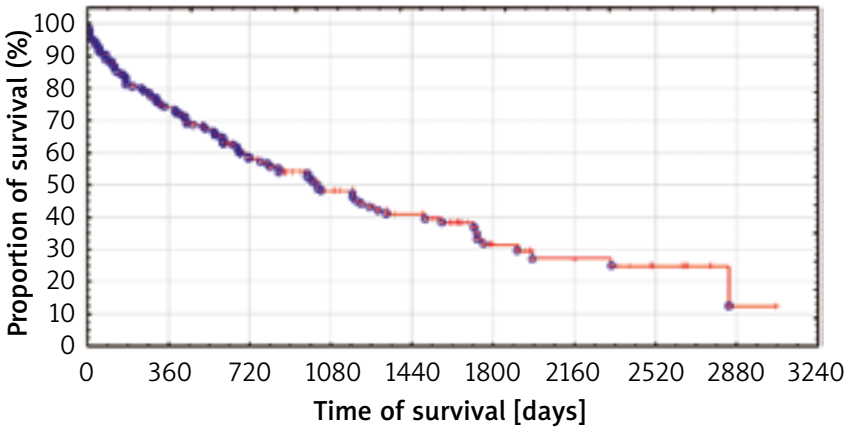

Fig. 1. Overall survival for all studied patients (Kaplan-Meier test)

$10 \%$ to as low as $0 \%[2,9-12]$. Coexisting cardiovascular and respiratory diseases as well as reduced parameters of respiratory function tests result in a higher perioperative risk compared to younger patients, and thus also impact the long-term outcome after pulmonary resections. In numerous reports, extensive pulmonary resections, especially pneumonectomies, performed in elderly patients with lung cancer, have a significant negative impact on long-term results $[2,13]$. The use of more sophisticated bronchoplastic procedures to avoid pneumonectomy gives a better chance of reaching a similar outcome to lobectomy or bilobectomy [14]. On the other hand, some authors suggest performing sublobar resections in early stage lung cancer, particularly in higher risk elderly patients with poor pulmonary reserve $[15,16]$. These operations are less invasive and are associated with a lower rate of severe postoperative complications and mortality comparable to lobectomy as well as similar overall survival in comparison to lobar resections $[4,15,16]$.

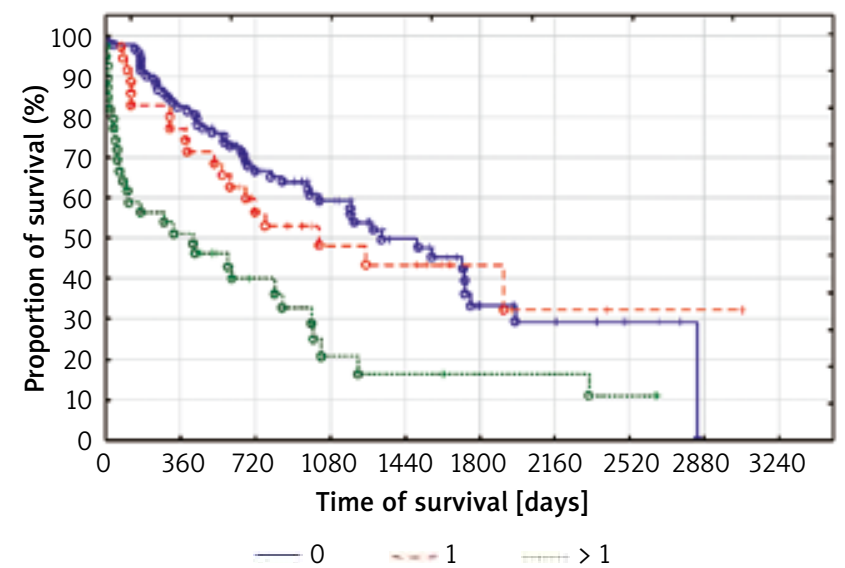

Detailed statistical analysis of the influence of number of complications on long-term survival - log-rank test

\begin{tabular}{ll} 
Clinical stage & $P$-value \\
0 vs. 1 & 0.61538 \\
\hline 0 vs. 2 & 0.00034 \\
\hline 1 vs. 2 & 0.01100 \\
\hline
\end{tabular}

${ }^{1}$ Log-rank test.

Fig. 3. Influence of number of postoperative complications on longterm survival - Kaplan-Meier test

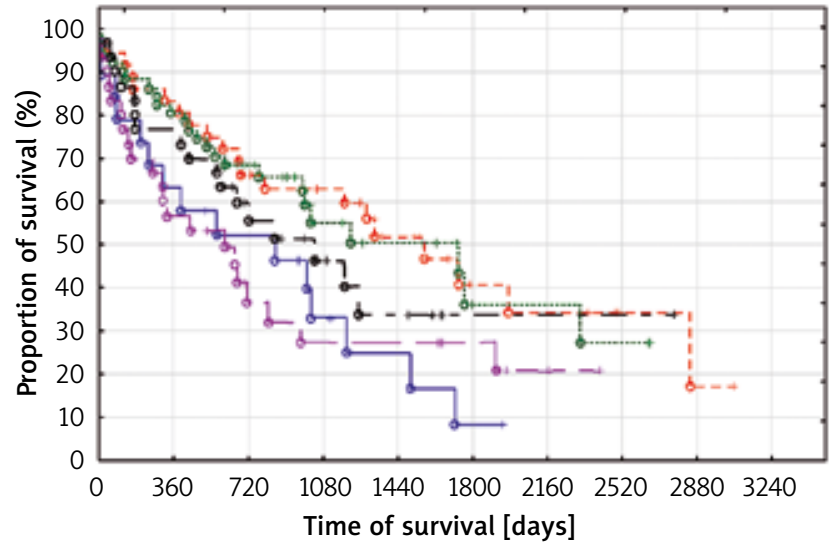

- IIB $\quad-. \mathrm{IA} \quad-\mathrm{IB} \quad-$ IIIA $\quad$ A

Detailed statistical analysis of the influence of histopathological stage of lung cancer (TNM) on long-term survival - log-rank test

\begin{tabular}{lc} 
Clinical stage & $P_{\text {-value }}{ }^{1}$ \\
IA vs. IB & 0.7776 \\
\hline IA vs. IIA & 0.3095 \\
\hline IA vs. IIB & 0.0264 \\
\hline IA vs. IIIA & 0.0407 \\
\hline IB vs. IIA & 0.3721 \\
\hline IB vs. IIB & 0.0300 \\
\hline IB vs. IIIA & 0.0342 \\
\hline IIA vs. IIB & 0.2729 \\
\hline IIA vs. IIIA & 0.2026 \\
\hline IIB vs. IIIA & 0.9312
\end{tabular}

${ }^{1}$ Log-rank test.

Fig. 2. Influence of histopathological stage of lung cancer (TNM) on long-term survival - Kaplan-Meier test

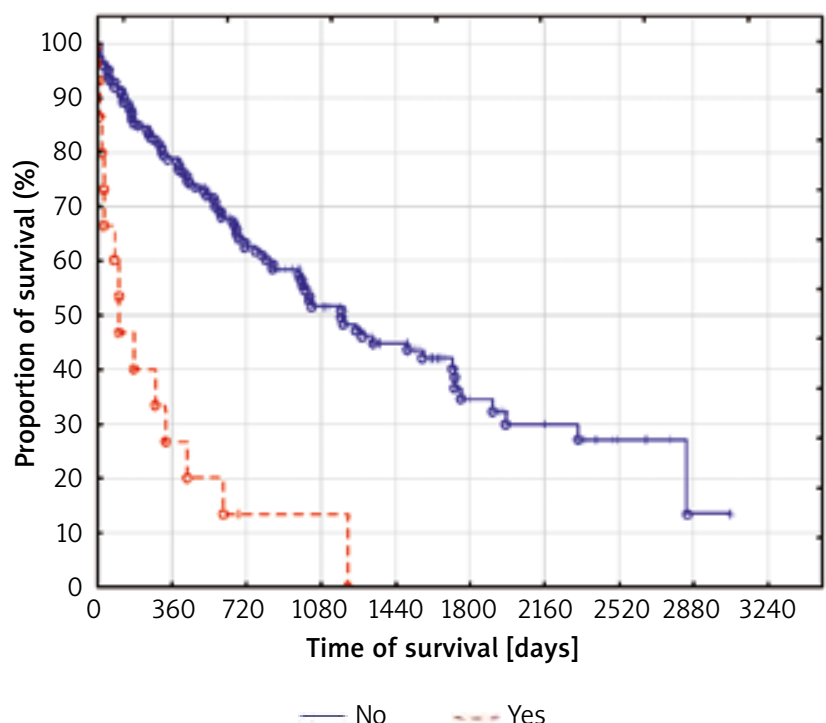

Fig. 4. Influence of atelectasis requiring bronchoaspiration on long-term survival - Kaplan-Meier test 
Table V. Influence of surgical approach and type of pulmonary resection on long-term outcome

\begin{tabular}{|c|c|c|c|}
\hline Characteristics & $\begin{array}{c}\text { Total number } \\
\text { of patients } \\
(N=166) \\
\%(n)\end{array}$ & $\begin{array}{c}\text { 1/3/5-year } \\
\text { survival } \\
(\%)\end{array}$ & $P$-value ${ }^{1}$ \\
\hline \multicolumn{3}{|l|}{ Operative approach: } & 0.8681 \\
\hline $\begin{array}{l}\text { Anterio-lateral } \\
\text { thoracotomy }\end{array}$ & $72(119)$ & $71 / 43 / 33$ & \\
\hline VATS & $28(47)$ & $87 / 48 / 27$ & \\
\hline \multicolumn{3}{|l|}{ Type of resection: } & 0.6834 \\
\hline $\begin{array}{l}\text { Lobectomy } \\
\text { or bilobectomy }\end{array}$ & $74(122)$ & $74 / 47 / 36$ & \\
\hline Pneumonectomy & $5(8)$ & $62 / 50 / 0$ & \\
\hline $\begin{array}{l}\text { Segmentectomy } \\
\text { or wedge resection }\end{array}$ & $22(31)$ & $80 / 50 / 22$ & \\
\hline
\end{tabular}

$P$-value $<0.05$ - statistically significant, $p \geq 0.05$ - statistically not significant. ${ }^{1}$ Log-rank test.

The introduction of minimally invasive videothoracoscopic surgical techniques, which were successfully adopted especially in elderly patients' lung cancer surgery and are becoming more and more involved in the total pulmonary resections of lung cancer, allowed both intraoperative injuries and the incidence of perioperative complications to be reduced. As previously reported, these operations also have a long-term outcome comparable to those performed by thoracotomy [17-19]. However, the use of videothoracoscopy is limited to the early stages of cancer.

Although the early stage of the disease gives a relatively good 5 -year prognosis for patients and ranges from $48 \%$ to $60 \%$, the more advanced cancers in stage III rapidly reduce the long-term survival to $16.5-0 \%[10,11,13,20]$. An advanced stage of cancer also concerns nonradical resections due to the $\mathrm{N} 2$ value, which significantly worsens the postoperative prognosis compared to younger patients [13].

In previous reports, lower long-term overall survival was influenced by gender (male), preoperative dyspnoea, low respiratory reserve, pneumonectomy, extended resection, $\mathrm{N}(1-2)$ subgroups and a pathological TNM stage [4, 9, 10, 13].

In this study, we completed a 5-year follow-up in 54 out of 166 subjects (33\%), with the survival rate reaching approximately $30 \%$. The 1-year survival rate in 166 patients was $74 \%$, while at the 3 -year follow-up it was $54 \%$ of the 103 patients. These observations are similar to the longterm results in younger patients, which varied from $30 \%$ to $69 \%$ depending on TNM stage $[2,21]$. In previous reports, the 5-year survival in elderly patients with lung cancer after radical pulmonary resection ranged from $30 \%$ to $62 \%[2,4$, $5,9,10,13,14]$.

The clinical stage of lung cancer according to the TNM Classification also significantly influenced the outcome in our patients. The most important differences were found between the early stages (IA or IB) and the most advanced
IIB or IIIA tumours. Our observations were similar to the results of other authors, in which more advanced stages of cancer shorten the total patients' survival $[10,11,13,19]$.

The early postoperative mortality among our patients was $5 \%$. These values correspond to other reports $[9,10]$. However, in our study, the radicality of surgical extent did not have a significant effect on the long-term outcome. VATS resections represented $28 \%$ of all our performed procedures; however, they had no statistically significant effect on long-term survival compared to standard thoracotomy.

Complications in the early postoperative period concerned $48 \%$ of our patients, which is comparable to others reports, where it ranged from $42 \%$ to $55 \%$ [3, 13, 22, 23]. In the majority of cases, these complications were transient and not life-threatening. The occurrence of total complications did not affect the long-term survival in our patients; however, the presence of more than 1 complication significantly impacts the lower long-term survival among our patients.

Among all the factors which significantly influenced the lower survival rate in our patients was postoperative obstructive atelectasis, requiring repetitive bronchofibroscopic aspiration. As supposed, this complication, which occurs in elderly patients more frequently, might be influenced by a number of factors, including respiratory distress following pulmonary resection, hypersecretion in emphysema or COPD, poor pulmonary function ( $\left.\mathrm{FEV}_{1}, \mathrm{FVC}\right)$, chest restriction due to postoperative pain, and long-term smoking of cigarettes [13, 24]. It is interesting that none of these risk factors affect the lower long-term survival in our patients. Atelectasis is particularly dangerous in elderly patients who have a reduced respiratory reserve. This complication is one of the most frequent in patients with advanced age [10]. A proper preoperative evaluation of these patients based on respiratory and circulatory function tests, the use of epidural anaesthesia, minimally invasive techniques, bronchodilator drugs, early postoperative rehabilitation and mobilisation of the patient, all seem to be important in minimising this complication.

\section{Conclusions}

Surgical resections for lung cancer in patients over 75 years of age are characterised by relatively good longterm prognosis. Careful and strictly detailed preoperative selection, particularly of patients with pulmonary comorbidities and the earliest possible diagnosis of a lung tumour, can reduce the occurrence of these postoperative complications in elderly patients, which negatively influence the long-term results.

\section{Disclosure}

Authors report no conflict of interest.

\section{References}

1. Glotzer OS, Fabian T, Chandra A, Bakhos CT. Non-small cell lung cancer therapy: safety and efficacy in the elderly. Drug Healthc Patient Saf 2013; 22: $113-121$. 
2. Zuin A, Marulli G, Breda C, Bulf R, Schiavon M, Rebusso A, Di Chiara F, Rea F. Pneumonectomy for lung cancer over the age of 75 years: is it worthwhile? Interact Cardiovasc Thorac Surg 2010; 10: 931-935.

3. Ogawa F, Wang G, Matsui Y, Hara H, lyoda A, Satoh Y. Risk factors for postoperative complications in the elderly with lung cancer. Asian Cardiovasc Thorac Ann 2013; 21: 313-318.

4. Dell'Amore A, Monteverde M, Martucci N, Sanna S, Caroli G, Dolci G, Dell'Amore D, Rocco G. Lobar and sub-lobar lung resection in octogenarians with early stage non-small cell lung cancer: factors affecting surgical outcomes and long-term results. Gen Thorac Cardiovasc Surg 2015; 63: 222-230.

5. Dillman RO, Zusman DR, McClure SE. Surgical resection and long-term survival for octogenarians who undergo surgery for non-small-cell lung cancer. Clin Lung Cancer 2009; 10: 130-134.

6. Liu HC, Huang WC, Wu CL, Huang JT, Chen CH, Chen YJ. Surgery for elderly lung cancer. Ann Thorac Cardiovasc Surg 2013; 19: 416-422.

7. Brokx HA, Visser O, Postmus PE, Paul MA. Surgical treatment for octogenarians with lung cancer: results from a population-based series of 124 patients. J Thorac Oncol 2007; 2: 1013-1017.

8. Nakagawa T, Negoro Y, Matsuoka T, Okumura N, Dodo Y. Comparison of the outcomes of stereotactic body radiotherapy and surgery in elderly patients with cT1-2NOMO non-small cell lung cancer. Respir Investig 2014; 52: 221-226.

9. Rostad H, Naalsund A, Strand TE, Jacobsen R, Talleraas O, Norstein J. Results of pulmonary resection for lung cancer in Norway, patients older than 70 years. Eur J Cardiothorac Surg 2005; 27: 325-328.

10. Dell'Amore A, Monteverde M, Martucci N, Sanna S, Caroli G, Stella F, Dell'Amore D, Rocco G. Early and long-term results of pulmonary resection for non-small-cell lung cancer in patients over 75 years of age: a multi-institutional study. Interact Cardiovasc Thorac Surg 2013; 16: 250-256.

11. Pagni S, McKelvey A, Riordan C, Federico JA, Ponn RB. Pulmonary resection for malignancy in the elderly: is age still a risk factor? Eur J Cardiothorac Surg 1998; 14: 40-4.

12. Dyszkiewicz W, Pawlak K, Gasiorowski L. Early post-pneumonectomy complications in the elderly. Eur J Cardiothorac Surg 2000; 17: 246-250.

13. Dominguez-Ventura A, Cassivi SD, Allen MS, Wigle DA, Nichols FC, Pairolero $\mathrm{PC}$, Deschamps C. Lung cancer in octogenarians: factors affecting longterm survival following resection. Eur J Cardiothorac Surg 2007; 32: 370-374.
14. Bölükbas S, Eberlein MH, Schirren J. Pneumonectomy vs. sleeve resection for non-small cell lung carcinoma in the elderly: analysis of short-term and long-term results. Thorac Cardiovasc Surg 2011; 59: 142-147.

15. Okada A, Hirono T, Watanabe T. Safety and prognosis of limited surgery for octogenarians with non-small-cell lung cancer. Gen Thorac Cardiovasc Surg 2012; 60: 97-103.

16. Tsutani Y, Tsubokawa N, Ito M, Misumi K, Hanaki H, Miyata Y, Okada M. Postoperative complications and prognosis after lobar resection versus sublobar resection in elderly patients with clinical stage I non-small-cell lung cancer. Eur I Cardiothorac Surg 2018; 53: 366-371.

17. Qiang G, Liang C, Guo Y, Shi B, Tian Y, Song Z, Liu D. Video-assisted thoracoscopic lobectomy for elderly nonsmall cell lung cancer: short-term and long-term outcomes. J Cancer Res Ther 2015; 11: 793-797.

18. Lee PC, Nasar A, Port JL, Paul S, Stiles B, Chiu YL, Andrews WG, Altorki NK. Long-term survival after lobectomy for non-small cell lung cancer by video-assisted thoracic surgery versus thoracotomy. Ann Thorac Surg 2013; 96: 951-960.

19. Srisomboon C, Koizumi K, Haraguchi S, Mikami I, lijima Y, Shimizu K. Thoracoscopic surgery for non-small-cell lung cancer: elderly vs. octogenarians. Asian Cardiovasc Thorac Ann 2013; 21: 56-60.

20. Fanucchi O, Ambrogi MC, Dini P, Lucchi M, Melfi F, Davini F, Mussi A. Surgical treatment of non-small cell lung cancer in octogenarians. Interact Cardiovasc Thorac Surg 2011; 12: 749-753.

21. Palma DA, Tyldesley S, Sheehan F, Mohamed IG, Smith S, Wai E, Murray N, Senan S. Stage Me non-small cell lung cancer (NSCLC) in patients aged 75 years and older: does age determine survival after radical treatment? J Thorac Oncol 2010; 5: 818-824.

22. Rueth NM, Parsons HM, Habermann EB, Groth SS, Virnig BA, Tuttle TM, Andrade RS, Maddaus MA, D'Cunha J. Surgical treatment of lung cancer: predicting postoperative morbidity in the elderly population. J Thorac Cardiovasc Surg 2012; 143: 1314-1323.

23. Takamochi K, Oh S, Matsuoka J, Suzuki K. Risk factors for morbidity after pulmonary resection for lung cancer in younger and elderly patients. Interact Cardiovasc Thorac Surg 2011; 12: 739-743.

24. Suemitsu R, Takeo S, Hamatake M, Yoshino J, Motoyama M, Tanaka H. The perioperative complications for elderly patients with lung cancer associated with a pulmonary resection under general anesthesia. J Thorac Oncol 2009; 4: 193-197. 